\title{
Sciendo
}

\section{The impact of educated migrants and R\&D expenditures on innovation}

\author{
Elena-Alexandra SINOI \\ West University of Timisoara, Timisoara, Romania \\ elena_sinoi@yahoo.com
}

\begin{abstract}
Migration has become a topic of great interest of the 21st century, as it triggers multiple advantages and downsides, both for the people and communities implicated, depending on the policies in place. International migration should not be perceived as an issue that needs to be solved, but rather a global phenomenon that can reduce poverty and foster inclusive growth and sustainable development, both in origin and destination countries. The most highly-skilled immigrants represent a key factor in enhancing innovation and technological change processes, which are essential aspects of social and economic development. The purpose of the study is to analyse the impact of highly educated immigrants (with tertiary-educated immigrant employees and foreign PhD students) together with $R \& D$ investments on innovative activity (proxied by the number of patents applications), in the case of the ten countries which joined the EU in 2004. The evaluated time frame is from 2011 to 2017. For the econometric analysis of the panel data, we developed fixed-effects linear regression models, at the country-level. The indicators computed are relevant to the innovative activity. The econometric estimations highlight a positive correlation between educated migrants and the number of patent applications in all ten countries. This nexus is even strengthened when we take into consideration other relevant impact factors, such as investments in R\&D and human capital. Therefore, the more efforts and investments are devoted to R\&D and highly educated individuals, the more predictable the innovation is.
\end{abstract}

Keywords: educated immigrants, innovation, patents, R\&D, EU countries.

Please cite the article as follows: Sinoi, E.A. (2021), "The impact of educated migrants and R\&D expenditures on innovation", Management \& Marketing. Challenges for the Knowledge Society, Vol. 16, No. 1, pp. 13-25. DOI: 10.2478/mmcks-2021-0002.

\section{Introduction}

Migration (permanent or temporary) has become a topic of great interest of the 21st century, as it triggers multiple advantages and downsides, both for the people and communities implicated, depending on the policies in place (IOM, 2018).

International migration should not be perceived as an issue that needs to be solved, but rather a global phenomenon that can reduce poverty and foster inclusive and sustainable development, both in origin and destination countries (Foresti et al., 2018). Therefore, government authorities should cooperate at local, national, regional, and global levels to create circumstances in which migration is an option rather than a constraint. More efforts should be focused on the implementation of policies that promote legal

DOI: $10.2478 /$ mmcks-2021-0002 
migration, diminish the drawbacks, and valorise the benefits of these movements (IOM, 2018). Many governments already seek to implement effective R\&D investment policies to facilitate innovation and thus to improve the living standards and generate economic growth (Bilbao-Osorio and Rodriguez-Pose, 2004).

It is well known that talent represents the most precious resource in our contemporary knowledge-intensive economy. When speaking about talent, it is taken into consideration both education level and innate cleverness (Kerr, 2020). Therefore, in the contemporary globalized era, countless countries are in a race to attract those migrants who are highly skilled (Docquier and Machado, 2016). This type of immigrant is so meaningful in generating innovation and technological change processes, which are essential aspects of social and economic development (OECD, 2012).

As the exchanges of highly-qualified individuals ("brain exchanges") among countries represent a characteristic of globalization, only those countries that succeed to have a suitable exchange of skilled workers benefit from positive economic outcomes (Findlay and Lowell, 2016). There are some crucial elements which lure the highly educated people to migrate in a specific host country and stimulate them to be productive there. Among these factors are the policy in force of the patents' production and registration, the availability of highly qualified occupations (an appropriate job for one's qualification), the salary level and the country's/ firm culture (Venturini, 2013).

Educated migrants have tremendous contributions to technological development all over the world. Therefore, this topic needs permanent investigations so that the countries involved to benefit from the movement of skilled workers. Taking this into consideration, this research focuses on how the process of innovation is influenced by the highly-educated immigrants, along with R\&D investments in ten destination countries from the EU. The time frame is between 2011 and 2017 (this period covering the seven years after the global financial crisis of 2007-2010). For the econometric analysis of the data, STATA 14 econometric package was used.

\section{Literature review}

\section{Effects of migration on destination countries}

Human capital has a crucial role in generating economic growth, and more important than the size of the population (quantity of workforce) is the composition of the population (quality of workforce) (Romer, 1990). Lately, the interest in highly skilled immigrants has considerably grown all over the world. However, while some governments liberalised, even more, their skilled immigration policies, others implemented some restriction (Cerna, 2016).

Many studies highlight that the innovative performance in a country is greatly influenced by both internal factors (R\&D expenditures and skilled local employed workforce) and external factors (skilled foreign labour force) (Leiponen, 2005; Dima et al., 2019; Mohnen and Roller, 2005; Gagliardi, 2014).

Highly skilled immigrants have profound economic effects on destination countries (Nathan, 2014), which are wide and persistent in the medium to the long term (Bahar et al., 2020). The increase of the highly skilled human resources in a country (via the inflow of immigrants) stimulates job creation, catalyses both the productivity of the existing workforce and overall productivity (Jensen, 2014; Peri, 2016), conducting to a weighty increase in the national wealth (Borjas and Doran, 2012). Also, young educated immigrants 
enhance the size of the workforce and sustain the fiscal policy in destination country, by contributing positively to the public finances (Clements et al., 2015; Edo et al., 2018).

Migrants with a degree in science, technology, engineering, and mathematics fields (STEM migrants) represent a "brain gain" for receiving countries (an acquisition of educated workers), as they have a pivotal role in R\&D activity and knowledge creation (Miguelez and Noumedem Temgoua, 2020), and thus contribute to long-term productivity, and finally to economic growth (Gelb and Krishnan, 2018).

In recent research, Brown et al. (2019) study the relationship between foreign human capital and innovation in the U.S. high-tech sectors (with important implications on economic growth), using data from the U.S. Census Bureau's 2014 Annual Survey of Entrepreneurs. The authors underline that STEM migrants and immigrant entrepreneurs have greater contributions to higher innovation activities (product and process innovation, different forms of $\mathrm{R} \& \mathrm{D}$, trademarks, and patents) in comparison to native counterparts. Also, on average, foreigners tend to be much better educated than the U.S. born fellows in the high-tech sector.

In his study, Stuen et al. (2012) emphasize that immigrant students from doctoral programmes contribute positively to knowledge production in science and engineering fields (S\&E) in the US, together with domestic students, leading in sustainable development. Not only does the U.S. benefit from the inflow of foreign-educated workforce, but it also indirectly takes advantage of the educational investments made by the origin countries (Stephan and Levin, 2001).

Bahar et al. (2020) emphasise that highly skilled immigrants can genuinely shape the patent production function in the receiving country, by facilitating the conveyance of technological knowledge from the origin to the destination country. Therefore, the host country can acquire an advantage in the same technology in which the sending country is specialized (Miron et al., 2009).

Kerr and Lincoln (2010) provide similar evidence in their research on U.S. innovation emphasising that science and engineering immigrants contribute directly to technology creation and commercialization. Additionally, the authors found that local peers are not displaced by skilled foreigners therefore, the aggregate invention is spurred.

In a recent paper, Burchardi et al. (2020) analyse the extent to which immigrants increase the innovation and economic growth in U.S. countries. The results show that skilled foreign people represent a positive input for innovation (proxied by local firms patenting), contribute to job creation and increase local wages, with beneficial repercussions on overall welfare.

Studying the effects of migrants on the 34 OECD countries, in the year 2010, Aubry et al. (2016) found out that global migration flows (immigration and emigration) positively influence the well-being of $69 \%$ of the non-migrant citizens (the market-size effect of migration being the most significant source of welfare).

Therefore, developed countries perceive skilled foreigners as a necessity for their further technological innovation and respectively economic growth, and competitiveness in today's globalised economy (Crown et al., 2020).

The cultural diversity of tertiary-educated immigrants has a pivotal role in developing breakthrough innovation in a team (Ferrucci and Lissoni, 2019), boosts the performance of regional R\&D sectors (Niebuhr, 2010) and exerts a conclusive impact on the GDP per capita (Bove and Elia, 2017). 
In their study, Laursen et al. (2020) find that diversity and complementary between workers are essential aspects of a company's innovations quality. Due to the diverse techniques on innovation-related problem-solving, highly skilled foreign workers have a greater impact on innovation activity at a firm-level in comparison with highly skilled native workers.

Studying the influence of Soviet immigrant inventors on Germany technological innovation, Ferrucci (2020), finds that the collaboration between the native inventors and migrant Soviet scientists increases the patent production and the technology diversion.

An increase in the share of skilled immigrants raises GDP per capita (people's wellbeing) in the recipient countries in the long run, mainly by enhancing the productivity per worker. Educated migrants either have themselves high levels of productivity or provide complementary skills to their local counterparts, with positive effects on aggregate productivity (Jaumotte et al. 2016). Therefore, immigrants may indeed complement native individuals at the workplace (both sides taking advantage of the collaboration) and not necessarily compete with them, as there is no perfect substitutability between migrants and natives (Ottaviano and Peri, 2012).

Not only in the long-term or permanent migration enhances the knowledge circulation and innovation diffusion, but also in the short-term labour movements. Mbaye and Tani (2019) study the causal relationship between short-term work-related inflows and innovation (estimated through the products, services, and processes development) in the case of 34 African countries. The authors found a positive nexus between the two variables, with positive consequences on economic growth and poverty alleviation.

In addition to the countless benefits brought by immigrants in the destination country, it also encounters some disadvantages more or less deleterious. Some individuals from receiving countries may perceive foreigners as a threat to the economy as a whole and not as a potential source of future economic gains.

For instance, migration flow could increase public expenditures; the productivity of some local individuals may be harmed; native-born counterparts who are most susceptible to be substituted at the workplace by immigrants may face wage declines or diminished labour market opportunities (Borjas, 2003); high levels of immigration hamper the export sophistication of some countries, and therefore negatively affects the economic performances (Chletsos and Roupakias, 2019).

Studying the impact of foreign students in graduate programs on the native U.S. students, Borjas (2004) ascertained that the immigrants' enrolling in graduate education negatively affects the decisions/ incentives of white native men to follow the same programs, especially at the best institutions.

In a similar research, Borjas (2006) purport that immigrant students from doctorate programs lead to a decline in the wages of highly skilled competing workers (both indigenous and foreign peers) from the same fields, hindering their economic opportunities. Therefore, native workers might be influenced to follow some professions and stay away from others.

In their research, Borjas and Doran (2012), study the spillover effects of the highly skilled Soviet immigrants on the productivity of the mathematics market from the USA. The results show a decrease in the productivity of local mathematicians whose research programs corresponded to that of the Soviet migrants. 
All in all, the migration of skilled workforce generates a global welfare, as the advantages gained by the destination countries overtake the drawbacks faced by some countries of origin (Biavaschi et al., 2020).

\section{Effects of migration on origin countries}

For sending countries, the emigration, especially of high-skilled individuals may represent either a "brain drain" (an exodus of skilled human capital) or a "beneficial brain drain" (an optimal emigration level of educated workers, from which origin country may benefit), depending on the country-specific characteristics and policy targets (Docquier, 2014). The return of the skilled migrants (who have acquired qualifications/ achieved expertise abroad) may stimulate productivity in the origin country, and thus diminish the negative effects that have occurred initially (Findlay and Lowell, 2016).

On one hand, migrants and diaspora promote knowledge and technology transfer from the destination country back to the home country, send substantial remittances to their relatives and invest in entrepreneurship by setting up businesses in origin countries (UNCTAD, 2009). Hence, when the migration is well managed and supported by adequate and efficient policies, it ensures positive effects on origin countries, contributing to domestic innovation and accelerating economic growth (UN, 2017).

Fackler et al. (2019) emphasise that emigrants encourage knowledge and technology diffusion in their source countries, contributing indirectly to innovation enhancement. Even though the origin countries initially face brain drain because of the mobility of the highly educated workforce, yet they may benefit from knowledge remittances.

In a similar vein, Choudhury (2015) studies how return migrants stimulate knowledge production among their employees in the origin country. The results show that local employees whose managers are return migrants record much more numbers of patents in comparison to their local peers who have local managers.

Studying the effects of highly skilled emigration on five origin countries Gibson and McKenzie (2012) show that the potential economic costs of migration flows are surpassed by the benefits induced in sending country. The diaspora usually remits money to home country and is involved in knowledge transfers, trade, and foreign direct investments.

On the other hand, for home countries, the migration of highly-skilled individuals may lead into a deprivation of qualified human capital, which deepens the disparities between the developed (receiving) and developing (sending) countries (Djiofack et al., 2013).

Gaule (2011) found that the most successful academic scientists that migrate to the U.S. are less expected to return in their source country, this fact being rather worrisome from the home countries point of view.

In their study, Docquier and Iftikhar (2019) found that the emigration of skilled workforce from 33 sub-Saharan African countries harms the low skilled population welfare. However, these welfare decreases differ between countries, according to the country's productivity, training technology and education.

As an idea drawn from all the above studies carried out by different researchers, it is clear that highly-educated immigrants represent an essential tool in technological development, especially in destination countries. But, the innovation intensity depends on both the characteristics of the countries involved and the type of education of immigrants. 


\section{Research methodology \\ Aim of the research}

The purpose of the study is to analyse the nexus between highly-educated immigrants, R\&D investments and the innovative activity, in the case of the ten countries which joined the EU in 2004, namely the Czech Republic, Cyprus, Estonia, Latvia, Lithuania, Malta, Poland, Slovakia, Slovenia and Hungary. It is intended to investigate how the process of innovation has evolved in these countries, subsequent to the adherence to the EU.

The evaluated time frame is from 2011 to 2017. This period covers the seven years after the global financial crisis of 2007-2010. The year 2011 was the first year post-crisis, and the year 2017 was the most recent year for which the majority of the data could be found.

Taking into consideration the previous studies with regard to the link between highly-educated migration and innovation, and in order to reach the aim of my research, the following main hypotheses are tested:

- H1: Highly educated migrants have an important contribution to the development of ideas and knowledge.

- H2: The more R\&D investments are made the more innovation is spurred.

\section{Data}

For the econometric analysis of the panel data, were developed fixed-effects linear regression models, at the country-level. The indicators computed are relevant to the innovative activity, and the dataset forms a strongly balanced panel for the period between 2011 and 2017.

Raw data was collected from the Eurostat-European Commission database and it was computed by using STATA 14 econometric package.

The estimated empirical model has the following form:

$$
\ln \left(\text { Innovation }_{i t}\right)=\alpha_{0}+\alpha_{1} * \ln \left(\text { Migrant }_{i t}\right)+\alpha_{2} * \ln \left(X_{i t}\right)+\varepsilon_{i t}
$$

where,

- $\ln \left(\right.$ Innovation $\left._{i t}\right)$ represents the response variable and is the natural logarithm of the number of patent applications per one million inhabitants (at the European Patent Office by priority year), in country i, over the time interval t. Bottazzi and Peri (2003) purport that patent applications are a good measure of the innovative activity;

- $\ln$ (Migrantit) is an explanatory variable (representing the variable of interest) and includes the natural logarithm of immigrant employees with tertiary education, age from 25 to 64 years (\%) and foreign doctoral students (\% of all doctoral students);

- $\ln \left(\mathrm{X}_{\mathrm{it}}\right)$ is also an explanatory variable and represents a vector of relevant controls that includes the natural logarithm of intramural R\&D expenditure by sectors of performance (all sectors, business sector, government sector and higher education sector, \% of GDP); HRST (human resources with tertiary education and employed in science and technology, age from 25 to 64 years, \% of the total population); employment in knowledge-intensive activities ( $\%$ of total employment); total R\&D personnel and Researchers by sectors of performance (all sectors, business sector, 
government sector and higher education sector, \% of the total labour force); and Gross Domestic Product in purchasing power standard per capita;

- $\alpha_{0}$ represents the constant and $\varepsilon_{i t}$ the residual term.

\section{Descriptive statistics}

Table 1 contains the descriptive statistics of the full sample (non-logarithmic data version), between 2011 and 2017. It includes the number of observations, the average value, the standard deviation, the minimum and the maximum values of the variables.

Table 1. Descriptive statistics

\begin{tabular}{|c|c|c|c|c|c|}
\hline Variable & Obs & Mean & Std. Dev. & Min & Max \\
\hline Patents & 70 & 20.28586 & 15.08176 & .8 & 65 \\
\hline Ed_empl_immi & 70 & 76.00486 & 6.191017 & 57.5 & 94. \\
\hline Foreign_doct & 70 & 15.762 & 23.16496 & .2 & 86. \\
\hline Empl KIA & 70 & 13.73 & 4.113969 & 8.8 & 22 . \\
\hline$\overline{\mathrm{H}} \mathrm{RST}$ & 70 & 15.82714 & 3.227595 & 9.8 & 22 . \\
\hline RD_pers_all & 70 & 1.011429 & .2655608 & .5 & 1. \\
\hline $\mathrm{RD}^{-1}$ pers bus & 70 & .2897143 & .1640252 & .08 & .7 \\
\hline $\mathrm{RD}^{-}$pers gov & 70 & .1271429 & .0646539 & .01 & .2 \\
\hline RD_pers_edu & 70 & .5872857 & .2015514 & .33 & 1.1 \\
\hline $\mathrm{RD}_{-}^{+} \exp { }_{-}^{-} \mathrm{all}$ & 70 & 1.152857 & .5848972 & .44 & 2. \\
\hline $\mathrm{RD}_{-}$exp_bus & 70 & .6282857 & .4966758 & .07 & 1.9 \\
\hline RD_exp_gov & 70 & .185 & .0947881 & .01 & .3 \\
\hline $\mathrm{RD}^{-}$exp edu & 70 & .3277143 & .1392857 & .13 & .7 \\
\hline $\mathrm{GD} \overline{\mathrm{P}} \_\mathrm{pc}$ & 70 & 21404.29 & 2973.186 & 14900 & 2930 \\
\hline
\end{tabular}

Source: Authors' own computation on the dataset in STATA 14.

In this research, we study the case of ten countries for seven years, which results in 70 observations.

The greatest number of patent applications per million inhabitants was in Slovenia, in 2014 (65.54) and the lowest number was in Malta, in 2011 (0.8). The highest percentage of tertiary-educated employed immigrants was in Slovakia, in 2013 (94.5\%), while the lowest percentage was in Slovenia, in 2013 (57.5\%). The highest percentage of foreign doctoral students (\% of all doctoral students) was in Lithuania, in 2015 (86.99\%) and the lowest percentage was in Latvia, in $2011(0.2 \%)$. The highest percentage of HRST (\% of the total population) was in Lithuania, in 2017 (22.3\%), while the lowest percentage was in Malta, in 2011 (9.8). The greatest share of R\&D expenditure in all sectors (\% of GDP) was in Cyprus, in 2012 and Latvia, in 2016 (2.56\% of GDP) and the lowest share was in Slovenia, in 2012 and 2013 ( $0.44 \%$ of GDP).

\section{Findings}

\section{Econometric results}

Table 2 presents the effects of highly-educated immigrants (tertiary-educated employed immigrants and foreign doctoral students), together with other significant variables (investments in R\&D and human capital), on the number of patent applications, between 2011 and 2017. Hausman Test was applied to verify whether a fixed-effect or a randomeffects model is suitable for this analysis. Therefore, it was generated a Prob $>\mathrm{chi} 2=0.0000$, 
meaning that the right model is the fixed-effect regression model (for a Prob>chi2 below 0.05 a fixed-effect model is appropriate (consistent)). All indicators are expressed in natural logarithm.

Table 2. The effects of educated immigrants on innovation (fixed-effects), 2011-2017

\begin{tabular}{|c|c|c|c|c|c|c|c|}
\hline & $\begin{array}{c}(1) \\
\text { Patents } \\
i t\end{array}$ & $\begin{array}{c}(2) \\
\text { Patents }_{i t}\end{array}$ & $\begin{array}{c}\text { (3) } \\
\text { Patents }\end{array}$ & $\begin{array}{c}(4) \\
\text { Patents }_{i t}\end{array}$ & $\begin{array}{c}(5) \\
\text { Patents } \\
\text { it }\end{array}$ & $\begin{array}{c}(6) \\
\text { Patents } \\
\text { it }\end{array}$ & $\begin{array}{c}\text { (7) } \\
\text { Patents }_{\text {it }}\end{array}$ \\
\hline Ed empl_immi & $\begin{array}{l}2.088 * * \\
(2.82)\end{array}$ & $\begin{array}{l}2.153 * * \\
(2.76)\end{array}$ & $\begin{array}{l}1.911 \text { ** } \\
(2.71)\end{array}$ & $\begin{array}{l}1.996 * \star \\
(2.68)\end{array}$ & $\begin{array}{l}2.483 * * \\
(3.28)\end{array}$ & & \\
\hline Foreign_doct_st & $\begin{array}{l}0.254^{\star} \\
(2.40)\end{array}$ & $\begin{array}{l}0.361 * * \\
(2.83)\end{array}$ & $\begin{array}{l}0.345 * * \\
(2.73)\end{array}$ & $\begin{array}{l}0.320 \star \\
(2.62)\end{array}$ & & $\begin{array}{l}0.299 * \\
(2.28)\end{array}$ & $\begin{array}{l}0.304 \text { * } \\
(2.45)\end{array}$ \\
\hline Empl kia & $\begin{array}{l}2.886^{\star} \\
(2.62)\end{array}$ & & & & $\begin{array}{l}4.496 * \star \star \\
(3.84)\end{array}$ & & \\
\hline HRST & & & $\begin{array}{r}2.160 \\
(1.66)\end{array}$ & & & & $\begin{array}{l}1.806^{\star} \\
(2.34)\end{array}$ \\
\hline$R \& D \_p e r s \_a l l$ & & $\begin{array}{r}0.983 \\
(1.48)\end{array}$ & & & & & \\
\hline R\&D_pers_edu & & & & $\begin{array}{l}1.571 \text { ** } \\
(2.69)\end{array}$ & & $\begin{array}{l}1.933 \text { ** } \\
(2.96)\end{array}$ & \\
\hline$R \& D \_p e r s \_b u s$ & & & & & & $\begin{array}{l}-0.481 \\
(-1.43)\end{array}$ & \\
\hline$R \& D \_a l l$ & & $\begin{array}{l}0.855^{\star} \\
(2.01)\end{array}$ & $\begin{array}{l}1.041 * \\
(2.67)\end{array}$ & $\begin{array}{l}0.822^{\star} \\
(2.11)\end{array}$ & $\begin{array}{l}1.282 \text { ** } \\
(3.20)\end{array}$ & $\begin{array}{l}0.976^{\star} \\
(2.13)\end{array}$ & \\
\hline$R \& D \_e d u$ & & & & & & & $\begin{array}{l}0.700 * \\
(2.28)\end{array}$ \\
\hline$R \& D \_b u s$ & $\begin{array}{l}0.632 * \star \\
(3.24)\end{array}$ & & & & & & \\
\hline GDP_pc & & $\begin{array}{r}0.350 \\
(0.47)\end{array}$ & $\begin{array}{l}-1.256 \\
(-0.94)\end{array}$ & $\begin{array}{c}0.935 \\
(1.33)\end{array}$ & & $\begin{array}{l}2.024 * \\
(2.12)\end{array}$ & \\
\hline Constant & $\begin{array}{l}-13.76^{\star *} \\
(-3.32)\end{array}$ & $\begin{array}{r}-10.80 \\
(-1.43)\end{array}$ & $\begin{array}{r}0.329 \\
(0.03)\end{array}$ & $\begin{array}{l}-14.97 * \\
(-2.08)\end{array}$ & $\begin{array}{l}-19.60 * \star \star \\
(-4.44)\end{array}$ & $\begin{array}{r}-17.60 \\
(-1.84)\end{array}$ & $\begin{array}{l}-1.993 \\
(-1.04)\end{array}$ \\
\hline R-squared (within) & 0.3815 & 0.3385 & 0.3449 & 0.3922 & 0.3241 & 0.3374 & 0.2559 \\
\hline Observations & 70 & 70 & 70 & 70 & 70 & 70 & 70 \\
\hline
\end{tabular}

Source: Authors' own computation on the dataset in STATA 14.

The dependent variable is the number of patent applications and the independent variables are highly-educated migrants (representing the variable of interest), R\&D expenditure and national human capital.

For each model, it is emphasised the constant, the within value of $\mathrm{R}^{2}$ (which indicates the proportion of variance of the endogenous variable that can be explained by the exogenous variable) and the number of observations (70).

In line with the vast existing literature, in all seven models, high-skilled human capital (from different fields) and R\&D expenditures (in different sectors) play an important role in fostering innovation. Both variables of interest have positive and statistically significant coefficients and, in all models, tertiary-educated employed immigrants seem to have a higher impact on patent applications in comparison to foreign doctoral students.

The first four models take into account simultaneously both variables of interest, together with different combinations of independent variables.

In the first model, all independent variables are positively associated with the dependent variable. Tertiary-educated employed immigrants and R\&D expenditure in the business sector are significantly at 5 per cent level, while foreign doctorate students and employment in knowledge-intensive activities are significantly at 10 per cent level. A $1 \%$ increase in tertiary-educated employed immigrants leads to an almost $2.1 \%$ increase in the number of patent applications per million inhabitants, while a $1 \%$ increase in foreign doctorate students result in an increase of the number of patent applications by $0.25 \%$. The value of $\mathrm{R}^{2}$ equal to 0.3815 denotes that this model accounts for 38 per cent of the total variance in the number of patents. 
In the second model, in combination with R\&D personnel and R\&D expenditures in all sectors, the two variables of interest have the greatest positive impact on patent applications, from the first four models, being significantly at 5 per cent level.

The third and fourth models are similar to the second model.

In the fifth model, the tertiary-educated employed immigrants and R\&D expenditure in all sectors are significantly at 5 per cent level while the employment in knowledgeintensive activities is significantly at a 1 per cent level. A $1 \%$ increase in tertiary-educated employed immigrants leads to a $2.5 \%$ increase in patent applications. R-squared of 0.3241 emphasizes that this model accounts for 32 per cent of the total variance in the number of patent applications.

It is emphasized the importance of R\&D personnel from higher education, being significantly at 5 per cent level (model 6) and of R\&D expenditure in higher education, being significantly at 10 per cent level (model 7).

Model 6 is the only model in which GDP per capita has statistical significance (being significantly at 10 per cent level).

\section{Regression plot}

Figures 1, 2 and 3 outline the regression plots for the interaction between the dependent variable (the number of patent applications) and the independent variables (the share of immigrant employees with tertiary education (figure 1), investments in R\&D (figure 2) and HRST (figure 3)), in all ten countries, between 2011 and 2017.

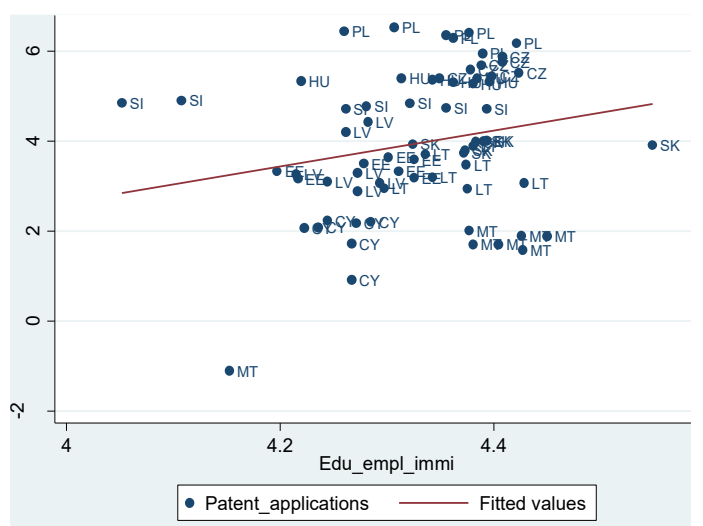

Figure 1. Patents vs. tertiary-educated employed immigrants, 2011-2017

Source: Authors' own computation on the dataset in STATA 14.

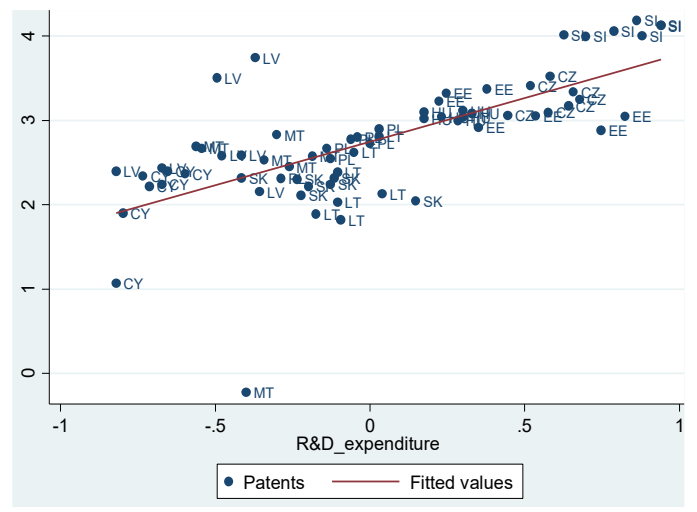


Figure 2. Patents vs. R\&D expenditure in all sectors, 2011-2017

Source: Authors' own computation on the dataset in STATA 14.

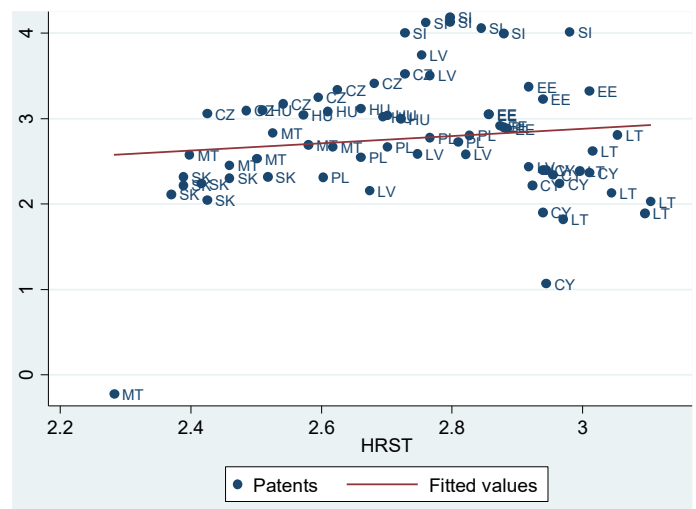

Figure 3. Patents vs. HRST, 2011-2017

Source: Authors' own computation on the dataset in STATA 14.

There is a positive and pretty high correlation between the number of patents and the share of educated immigrants employed, in all countries. Therefore, the more highly educated are the employed immigrants, the greater is the chance of a country to benefit from the development of new patents. As observed, this correlation is the tightest in Poland (figure 1).

In figure 2 it is emphasized a higher and tighter correlation between the R\&D expenditures and innovation activity. The best correlation is in Slovenia.

Also, it cannot be denied the importance of educated human capital employed in science and technology, which also plays a significant role in patent development. The best correlation seems to be in Slovenia (figure 3).

\section{Conclusion}

In the current globalized world, migration (permanent or temporary) represents a topic of intense focus, as it triggers multiple gains and drawbacks, both for the people and communities implicated, depending on the policies in place (IOM, 2018). Therefore, government authorities should cooperate at local, national, regional and global levels to implement policies that promote legal migration, limits the downsides and valorise the benefits of these movements (IOM, 2018).

Lately, an increasing number of countries are in a race to attract the most highlyskilled immigrants (Docquier and Machado, 2016), because they represent a key factor in fostering innovation, productivity and economic growth. Therefore, it is wrong to perceive international migration as a difficulty because, it represents an inevitable global phenomenon, that can defeat poverty and foster inclusive and sustainable development, both in origin and destination countries (Foresti et al., 2018).

As the migration of skilled workforce generates a global welfare (Biavaschi et al., 2020), countries should perceive skilled foreigners as a necessity for their further technological innovation, economic growth, and competitiveness in today's globalised economy (Crown et al., 2020).

This study analyses the effects of highly educated immigrants together with R\&D expenditures on the innovative activity, in the case of the ten countries which joined the EU 
in 2004, for the period between 2011 and 2017. The econometric analysis consists of the development of fixed-effects linear regression models, at the country-level, with all indicators computed being relevant to the innovative activity.

The econometric estimations highlight a positive correlation between educated migrants and the number of patent applications in all ten countries. In all models, tertiaryeducated employed immigrants seem to have a higher impact on patent applications in comparison to foreign doctoral students. This nexus is even strengthened when we take into consideration other relevant impact factors, such as investments in R\&D and human capital.

Therefore, highly-educated immigrants (employed or $\mathrm{PhD}$ students) play a significant role in patent development. Also, the more efforts and investments are devoted to $R \& D$, the more predictable the innovation is.

To sum up, the main hypotheses presented at the beginning of the study have been validated (H1: Highly educated migrants have an important contribution to the development of ideas and knowledge, and H2: The more R\&D investments are made, the more innovation is spurred).

The limit of this research is the short period took into consideration. The time frame between 2011 and 2017 covers the seven years after the global financial crisis of 20072010. The year 2011 was the first-year post-crisis, and the year 2017 was the most recent year for which the majority of the data were found.

\section{References}

Aubry, A., Burzyński, M., \& Docquier, F. (2016). The welfare impact of global migration in OECD countries. Journal of International Economics, 101, 1-21.

Bahar, D., Choudhury, P., \& Rapoport, H. (2020). Migrant inventors and the technological advantage of nations. Research Policy, 49(9), 103947.

Biavaschi, C., Burzyński, M., Elsner, B., \& Machado, J. (2020). Taking the skill bias out of global migration. Journal of Development Economics, 142, 102317.

Bilbao-Osorio, B., \& Rodriguez-Pose, A. (2004). From R\&D to Innovation and economic growth in the EU. Growth and Change, 35(4), 434-455.

Borjas, G. J. (2003). The labor demand curve is downward sloping: Reexamining the impact of immigration on the labor market. The Quarterly Journal of Economics, 118(4), 1335-1374.

Borjas, G. J. (2004). Do foreign students crowd out native students from graduate programs?. NBER Working Paper, 10349.

Borjas, G. J. (2006). Immigration in high-skill labor markets: the impact of foreign students on the earnings of doctorates. NBER Working Paper, 12085.

Borjas, G. J., \& Doran, K. B. (2012). The collapse of the Soviet Union and the productivity of American mathematicians. The Quarterly Journal of Economics, 127(3), 1143-1203.

Bottazzi, L., \& Peri, G. (2003). Innovation and spillovers in regions: evidence from European patent data. European Economic Review, 47(4), 687-710.

Bove, V., \& Elia, L. (2017). Migration, diversity, and economic growth. World Development, Elsevier, 89, 227-239.

Brown, J. D., Earle, J. S., Kim, M. J. \& Lee, K. M. (2019). Immigrant entrepreneurs and innovation in the US high tech sector. IZA Discussion Paper, 12190.

Burchardi, K., Chaney, T., Hassan, T. A., Tarquinio, L., \& Terry, S. (2020). Immigration, innovation, and growth. NBER Working Paper, 27075.

Cerna, L. (2016). The crisis as an opportunity for change? High-skilled immigration policies across Europe. Journal of Ethnic and Migration Studies, 42(10), 1610-1630. 
Chletsos, M., \& Roupakias, S. (2019). Immigration and the economic performance of countries. MPRA Paper, 94994.

Choudhury, P. (2015). Return migration and geography of innovation in MNEs: a natural experiment of knowledge production by local workers reporting to return migrants. Journal of Economic Geography, 16(3), 585-610.

Clements, B., Dybczak, K., Gaspar, V., Gupta, S., \& Soto, M. (2015). The fiscal consequences of shrinking population. IMF Staff Discussion Note 15/21.

Crown, D., Faggian, A., \& Corcoran, J. (2020). Foreign-born graduates and innovation: Evidence from an Australian skilled visa program. Research Policy, 49(9), 103945.

Dima, A. M.; Țuclea, C. E., Vrânceanu, D. M.; Țigu, G. 2019. "Sustainable Social and Individual Implications of Telework: A New Insight into the Romanian Labor Market" Sustainability 11, no. 13: 3506.

Djiofack, C.Z., Djimeu, E.W., \& Boussichas, M. (2013). Impact of qualified worker emigration on poverty: A macro-micro-simulation approach for an African economy. Journal of African Economies, 23(1), 1-52.

Docquier, F. (2014). The brain drain from developing countries: The brain drain produces many more losers than winners in developing countries. In Artal-Tur, A., Peri, G., Requena-Silvente, F. (Eds.). The Socio-Economic Impact of Migration Flows (pp. 123144). Population Economics, Springer, Cham.

Docquier, F., \& Machado, J. (2016). Global Competition for attracting talents and the world economy. The World Economy, 39(4), 530-542.

Docquier, F., \& Iftikhar, Z. (2019). Brain drain, informality and inequality: A search-andmatching model for sub-Saharan Africa. Journal of International Economics, 120, 109125.

Edo, A., Ragot, L., Rapoport, H., Sardoschau, S., \& Steinmayr, A. (2018). The effects of immigration in developed countries: Insights from recent economic research. EconPol Europe Policy Report, 2(22).

European Commission. Eurostat Database. Retrieved from https://ec.europa.eu/eurostat/data/database -

Fackler, T. A., Giesing, Y., \& Laurentsyeva, N. (2019). Knowledge remittances: Does emigration foster innovation?. Research Policy, 49(9), 103863.

Ferrucci, E., \& Lissoni, F. (2019). Foreign inventors in Europe and the United States: Diversity and patent quality. Research Policy, 48(9), 103774.

Ferrucci, E. (2020). Migration, innovation and technological diversion: German patenting after the collapse of the Soviet Union. Research Policy, 49(9), 104057.

Findlay, A., \& Lowell, B.L. (2016). Migration of Highly skilled persons from developing countries: Impact and policy responses. Working Papers, 11038.

Foresti, M. \& Hagen-Zanker, J. with Dempster, H. (2018). Migration and development: How human mobility can help achieve the sustainable development goals. In Migration and the 2030 Agenda for Sustainable Development (pp. 5-13). Overseas Development Institute.

Gagliardi, L. (2014). Does skilled migration foster innovative performance? Evidence from British local areas. Papers in Regional Science, 94(4), 773-794.

Gaule, P. (2011). Return migration: Evidence from academic scientists. Paper presented at DRUID Conference of 15-17 June 2011.

Gelb S. \& Krishnan, A. (2018). Technology, migration and the 2030 agenda for sustainable development. In Migration and the 2030 Agenda for Sustainable Development (pp. 181-198). Overseas Development Institute.

Gibson, J., \& McKenzie, D. (2012). The economic consequences of "Brain Drain" of the best and brightest: Microeconomic evidence from five countries. The Economic Journal, 122(560), 339-375.

International Organization for Migration. (2018). Migration and the 2030 agenda: A guide for practitioners. Retrieved from https://publications.iom.int/books/migration-and2030-agenda-guide-practitioners - 
Jaumotte, F., Koloskova, K., \& Saxena, S. C. (2016). Impact of migration on income levels in advanced economies. Spillover Note 8, International Monetary Fund.

Jensen, P. H. (2014). Understanding the impact of migration on innovation. Australian Economic Review, 47(2), 240-250.

Kerr, W., \& Lincoln, W. F. (2010). The supply side of innovation: H-1B visa reforms and U.S. Ethnic invention. Journal of Labour Economics, 28(3), 473-508.

Kerr, W. R. (2020). Global talent and U.S. immigration policy. Harvard Business School and NBER, Working Paper, 20-107.

Laursen, K., Leten, B., Nguyen, N. H., \& Vancauteren, M. (2020). Mounting corporate innovation performance: The effects of high-skilled migrant hires and integration capacity. Research Policy, 49(9), 104034.

Leiponen, A. (2005). Skills and innovation. International Journal of Industrial Organization, 23(5-6), 303-323.

Mbaye, L. M., \& Tani, M. (2019). Migration, innovation, and growth: An African story?. IZA Discussion Paper, 12533.

Miguelez, E., \& Noumedem Temgoua, C. (2020). Inventor migration and knowledge flows: A two-way communication channel?. Research Policy, 49(9), 103914.

Miron, D., Dima, A.M., Vasilache, S. (2009). Indexes of regional economic growth in postaccession Romania. Romanian Journal of Economic Forecasting, 11 (3), pp. 138-152.

Mohnen, P., \& Roller, L. H. (2005). Complementarities in innovation policy. European Economic Review, 49 (5), 1431-1450.

Nathan, M. (2014). The wider economic impacts of high-skilled migrants: a survey of the literature for receiving countries. IZA Journal of Migration, 3(1), 4.

Niebuhr, A. (2010). Migration and innovation: Does cultural diversity matter for regional R\&D activity?. Papers in Regional Science, 89(3), 563-585.

Organisation for Economic Co-operation and Development. (2012). Innovation for development: A discussion of the issues and an overview of work of the OECD directorate for science, technology and industry. Retrieved from https://www.oecd.org/innovation/inno/50586251.pdf -

Ottaviano, G. I. P., \& Peri, G. (2012). Rethinking the effect of immigration on wages. Journal of the European Economic Association, 10(1), 152-197.

Peri, G. (2016). Immigrants, productivity, and labor markets. Journal of Economic Perspectives, 30(4), 3-30.

Romer, P. M. (1990). Endogenous technological change. The Journal of Political Economy, 98(5), Part 2: The problem of development: A Conference of the institute for the study of free enterprise systems, 71-102.

Stephan P., \& Levin S. (2001). Exceptional contributions to US science by the foreign-born and foreign-educated. Population Research and Policy Review, 20 (1), 59-79.

Stuen, E.T., Mobarak, A.M., \& Maskus, K.E. (2012). Skilled immigration and innovation: evidence from enrolment fluctuations in US doctoral programmes. The Economic Journal, 122(565), 1143-1176.

United Nations Conference on Trade and Development. (2009). Ad hoc expert meeting on the contribution of migrants to development: Trade, investment and development linkages of 29 July 2009. Retrieved from https://unctad.org/meeting/ad-hoc-expertmeeting-contribution-migrants-development-trade-investment-and-developmental -

United Nations. (2017). International migration report 2017. Department of Economic and Social Affairs. Retrieved from https://www.un.org/development/desa/publications/international-migrationreport-2017.html -

Venturini, A. (2013). Innovation and human capital: The role of migration. MPC-RSCAS Policy Brief, 10. 